\title{
The Evaluation of Gambling Sector's Social Costs in Lithuania
}

\author{
Iveta Simberova $^{1}$, Rima Zitkiene ${ }^{2}$, Irena Macerinskiene ${ }^{2}$, Greta Geneliene ${ }^{2}$
}

${ }^{1}$ Brno University of Technology

Kolejni 2906/4, 61200, Brno, Czech Republic

E-mail.simberova@fbm.vutbr.cz

${ }^{2}$ Mykolas Romeris University

Ateities str. 20, LT-08303 Vilnius, Lithuania

E-mail.rizit3@mruni.eu; irena.macerinskiene@mruni.eu; grmorkevic@stud.mruni.eu

cross $^{\text {ref }}$ http://dx.doi.org/10.5755/j01.ee.31.5.25951

This article analyses the social costs of gambling sector in Lithuania. The aim of the research is to evaluate the change of gambling sector's gambling gross revenue according to the established right to submit a request to self-exclude from gambling since May 1, 2017. The scientific problem of the research is how to define and evaluate gambling sector's social costs. The analysis is conducted by evaluating dependency connection between gambling sector's gambling gross revenue and gross domestic product taking into account the changing quantity of requests to self-exclude from gambling and current economic situation in Lithuania. The following methods are used for analysis: graphical analysis, paired correlation analysis and linear regression analysis. First of all, the conception of the social cost of gambling is being analysed in the article. Then using previously specified methods the relationship between gambling sector's gambling gross revenue and gross domestic product in the country is evaluated. Using a linear regression equation, the model, showing how gambling gross revenue of gambling sector was expected to change in response to changes in the country's gross domestic product is obtained. According to gambling gross revenue for 2017-2019 the model reveals that gambling sector revenue, considering the change in gross domestic product, had a higher growth potential and the right to submit a request to self-exclude from gambling established in 2017 may have had a serious effect on slowing down the growth of gambling revenue.

Keywords: Gambling Sector; Social Costs; Externalities; General Domestic Product; Gambling Gross Revenue.

\section{Introduction}

Gambling, like other activities with negative externalities, causes not only positive but also negative effects to the economy. The negative impact of such activities is manifested through the social costs, i.e. some of the operating costs associated with the negative consequences of these activities are passed on to the society. As Barker and Britz (2000) observed ,gambling is, at best, problematic behaviour with good and bad consequences".

For many years scientists thought that economic growth and growing production are the essence of public welfare (Ginevicius, 2019). Currently scientists argue that economic growth does not improve people's lives and, therefore, cannot be considered as a goal of sustainable development. The social aspect of sustainable development is about increasing the social welfare for all people (Melnikiene et al., 2018). Volodzkiene (2018) pointed out that ,the economic growth of a country does not guarantee the increase of social welfare". At present researchers have concluded that gross domestic product is not the best tool to measure social welfare (Morkevicius, 2016).

As Lojpur and Draskovic (2013) correctly observed, the negative externalities created by business on the economy are directly related to the lack of social responsibility in business behaviour. Even though the primary purpose of business is to make profit, but for the sake of sustainable economic development, business must behave in a socially responsible manner (Lojpur \& Draskovic, 2013). Based on that, entities that carry out activities with negative externalities pay corrective taxes aimed at compensating the society for the actual harm, i.e. the social costs.

Since the legalization of gambling in Lithuania in 2001, the gambling sector was rapidly expanding. This sector has contributed to the creation of new jobs, the raising of the state budget through additional taxes and emergence of a new kind of addiction. Although the gambling sector in Lithuania is developing rapidly, since the beginning of gambling legalization in Lithuania, no analysis has been carried out to identify, analyse and evaluate the social costs of this sector.

Unfortunately, researchers (Philander, 2013; Grebliauskas, 2009; and others) often choose only the taxation system of the gambling sector as the object of research and the negative external effects caused by this sector are left only as a secondary object. Also, many scholars do not analyse the concept of social costs in their research and without examination choose social costs of gambling in their research accidentally (Goodman, 1994; Grinols, 2004; Chalaguine, 2018; and others). The economic concept of social costs was mainly analysed by Walker (2013) who tried to classify social costs into types and analysed social costs evaluated by other scientists. 
The analysis of the scientific literature revealed that no Lithuanian scientist paid attention to the analysis of the concept of social costs of gambling sector and did not analyse the impact of these costs on the economy to any extent. It can be stated that gambling in Lithuania has not received enough scientific attention and the impact of this sector's social costs is not evaluated. The novelty of the research is that after analysing the concept of social costs, it is assessed whether one of the social costs - the establishment of the Register of Self-excluded people from gambling had - an impact on the income of the gambling sector.

The gambling sector has been mainly analysed by researchers in the following respects: the social costs of the gambling sector to society (Walker \& Barnett, 1999; Grinols, 2004; Blaszczynski et al., 2004; Walker, 2008; Coryn et al., 2008; Philander, 2013; Walker, 2013; Walker \& Sobel, 2016; Chalaguine, 2018; Solferino et al., 2018), benefits of the gambling sector to the state economy (Grinols, 2004; Walker \& Jackson, 2013; Chalaguine, 2018), taxation system of the gambling sector (Coryn et al., 2008; Alarie \& Ingelman, 2008; Grebliauskas, 2009; Philander, 2013; Walker \& Hodges, 2018), public gambling policy (Grebliauskas, 2011), the impact of gambling on personal bankruptcy (Boardman \& Perry, 2007), gambling impact on criminality (Walker, 2008; Walker, 2010; Fiedler, 2013), responsible gambling (Blaszczynski et al., 2004; Walker et al., 2014).

The object of this article is social costs of gambling sector in Lithuania. The aim of the research is to evaluate the change of gambling sector's gambling gross revenue according to the established right to submit a request to self-exclude from gambling since May 1, 2017. The scientific problem of the article is how to define and evaluate social costs of gambling sector. The tasks of the article are: 1) to present the conception of the social costs; 2) to analyse connection between gambling gross revenue change and social costs in Lithuania.

The analysis of scientific literature used for theoretical part. The statistical data of Eurostat and Gaming Control Authority under the Ministry of Finance of the Republic of Lithuania are used for analytical part. Graphical analysis, paired correlation analysis and linear regression analysis methods are used to analyse and present the results of the research.

\section{The Difficult Conception of Social Costs of Gambling}

According to Walker and Sobel (2016), gambling is a field where social and economic impacts should be analysed together. In this case, social gambling analysis impacts economical gambling analysis because negative long-term gambling consequences (which are mostly related to disordered gamblers) like crime, bankruptcy, health and other problems (Walker \& Sobel, 2016), - social costs, have influence on gambling sector's economical evaluation (Walker \& Barnett 1999). As claimed by Grebliauskas (2009) „Providing normal quality entertainment services with negative externalities is gambling industry's activity”. Therefore, organizing of gambling activity causes negative external effects (externalities) - additional social costs to society for its negative consequences.

Seeking to rectify such market imperfections like externalities, state can affect market directly by becoming participant in the market or indirectly by determining regulations, taxes etc. When market contains externalities to social welfare, as a rule, state chooses to affect it indirectly (Stanikunas, 2010). The aim of determining new regulations and taxes is to change business behaviour and to make business incorporate negative externalities into product/service cost (Zickiene, 2007).

A. C. Pigou was the first economist which offered to use taxes like a tool to correct market imperfections, negative (positive) external effects. The essence of A. C. Pigou corrective taxes theory: existence of negative external effects in society means that company transfers part of its activity costs to other society members which are not participating in that activity, therefore tax rate should be the size which is equal to cover negative external effects costs at the optimum output. In this way taxes increase marginal costs and production is reduced to optimal size (Williams \& Siegel, 2013).

According to Philander (2013) the main purpose of corrective taxes is to make private companies internalize social costs which are caused by their activities. This scholar pointed out that activity is economically effective and can be executed if benefit from it is greater than production costs and social costs summed together. Consequently, before legalizing activity which obviously can cause social costs for society, the state should conduct detail analysis about that type of activity's economical effectiveness (Philander, 2013).

Walker and Barnett (1999) pointed out that external effects appear when one subject actions make influence to other subject's welfare. Although negative external effects are related to social costs, however this doesn't prove that all negative external effects are social costs. These scientists pointed out that even gambling is undoubtedly causing negative external effects to society, for scholars it's still especially important to separate technological externalities from pecuniary externalities (Walker \& Barnett, 1999).

For economical participants technological externalities establishes opportunity to transform production costs into production efficiency and in this way distorts effective distribution of resources. Pecuniary externalities make influence on prices and wealth distribution in society without making any real effect to society welfare (Walker \& Barnett, 1999). Activity which could cause differences of prices or changes of wealth value for the third party also could cause advantages and disadvantages, however they do not cause economical ineffectiveness. Therefore, difference between technological and pecuniary externalities is that pecuniary externalities do not establish ineffective distribution of resources in society (Holcombe \& Sobel, 2011).

In gambling, for instance, if one gambler loses his money and another gambler wins it, for the first gambler this event entailed pecuniary loss, for the second - generated profit, but for society's welfare this event does not make any impact, wealth was just redistributed in society (pecuniary externalities). However, if the first gambler became addicted to gambling and because of that he lost his job and started his treatment, the state has to redistribute its' resources to provide treatment, psychologist consultations etc., and that's because negative external effects caused by gambling creates additional social costs to society (technological externalities). 
Consequently, technological externalities distort the efficient distribution of resources, equilibrium in the market and in this way create social costs for society. Corrective taxes analysed in Pigouvian theory should be applied only to adjust technological externalities (Coryn et al., 2008).

Philander (2013) revealed that the size of gambling negative external effects could be determined by function in which the main unknown is the quantity of pathological gamblers in the society. According to this, gambling types that make the biggest influence in developing gambling addiction should be taxed more than types which make less impact to addiction growth.

The definition of social costs has always been interpreted differently by scholars in economics. This allowed to make different conclusions about the extent, size and impact on the economy of social costs caused by gambling negative external effects. Walker (2013) paid a lot of attention to economic analysis of the definition of social costs in the context of gambling. In his opinion, social costs in gambling are generated by psychological or emotional factors (treatment costs) created by redistribution of wealth between individuals, also the cost of recovery and cost of default. Therefore, social costs should not be computed by the value of uncovered loans (Walker, 2013). In Walker (2008) opinion, in economics social costs mean a decreasing entire social wealth caused by certain actions or government policy.

According to Walker (2013), social costs indicate the diminishing real social wealth in society, but the decrease of wealth should not be solely attributed to the decrease of monetary resources. For example, if the activity harms a certain group of the society and does not benefit any member of the society, the social costs will be equal to the sum of the real wealth losses of each harmed member of society. On the other hand, if an activity is harmful to some members of society, but as a result it benefits other members of society, and if the benefits to society are equal to the harm, it means that balance of real social wealth has not been changed and such activity does not cause any benefits or social costs to the society. In this case, redistributed social wealth from one member of society to another does not change the total amount of real social wealth in society (Walker, 2013).

This concept of social costs is based on the Pareto optimality theory, which states that changes in the state increase social welfare when these changes benefits at least one member of society without harming anyone at the same time. Pareto optimum is achieved when there is no alternative method of utilizing resources (improving the position of at least one member of society without harming at least one other society member) (Walker, 2013). There is no consensus between scientists what negative externalities should be considered as the economic social cost caused by gambling. Douglas M. Walker economic concept of social costs could be one of the most appropriate methods to identify gambling sector's social costs to society.

After summarizing researches by many scientists it can be concluded that the following costs create the economic social costs of gambling: costs of legal services and law enforcement agencies, costs of recruitment, costs of treatment, costs of outstanding loan recovery and other government expenditure (education, research, prevention, etc.). Technologies have huge impact on gambling sector, so conception of social costs of gambling will be developing and new types of social costs of gambling could appear in future (Walker \& Hodges, 2018). Noticeable, that economic social costs of gambling should be analysed considering the harm to society caused by gambling addiction and only negative technological externalities should be evaluated.

\section{Connection between Gambling Sector's Gambling Gross Revenue Change and Social Costs in Lithuania}

Gambling has been legalized in Lithuania since July 1, 2001. Before legalizing gambling in Lithuania the positive and negative aspects of this activity were not analysed, also gambling was not taxed in relation to the social costs it generates. Although there is a special corrective tax for gambling in Lithuania, however since the beginning of legalization no analysis of this sector economic impact has been carried out.

In order to evaluate social costs of gambling to the state it is important to identify the number of addicted gamblers and to determine the level of public expenditure spent to combat with gambling addiction and its consequences. Further in this article it will be analysed whether there is a connection between gambling gross revenue change in Lithuania and increasing quantity of requests to self-exclude from gambling since May 1, 2017.

From May 1, 2017 amendments to the Gaming Law of the Republic of Lithuania („Gaming Law”) entered into force. Since then every person has the right to submit a request to self-exclude from gambling. In order to implement the amendments to the Gaming Law, a Register of Self-excluded people from gambling (,the Register”) was established. Seeing that all the funds for the establishment of the Register were provided from the state budget, we can conclude that all establishment costs are social costs for society caused by increased number of addicted gamblers in Lithuania. Since economic social costs to society should be evaluated through the harm caused by the development of gambling addiction, we assume that every person on the Register is addicted to gambling.

After analysis of the data we can see a change in gambling gross revenue (,GGR") and a change in the number of valid requests to self-exclude from gambling since May 1, 2017 (see Figure 1).

As we can see until 2019 Q1 the number of valid requests to self-exclude from gambling (,requests”) has been growing steadily and from 2019 Q1 the number of valid requests is almost unchanged. The GGR of gambling operators has also been growing steadily since 2017 Q2 except for a temporary decline in revenue for several quarters. As demonstrated the growing number of requests didn't had a clear effect on GGR of gambling operators (all types of gambling were analysed). After paired correlation analysis of valid requests and GGR for separate types of gambling (from Q2 2017 to Q4 2019) the results did not produce a significant negative correlation, so it cannot be concluded that there is a direct negative impact of requests to GGR for separate types of gambling. 
Iveta Simberova, Rima Zitkiene, Irena Macerinskiene, Greta Geneliene. The Evaluation of Gambling Sector's...

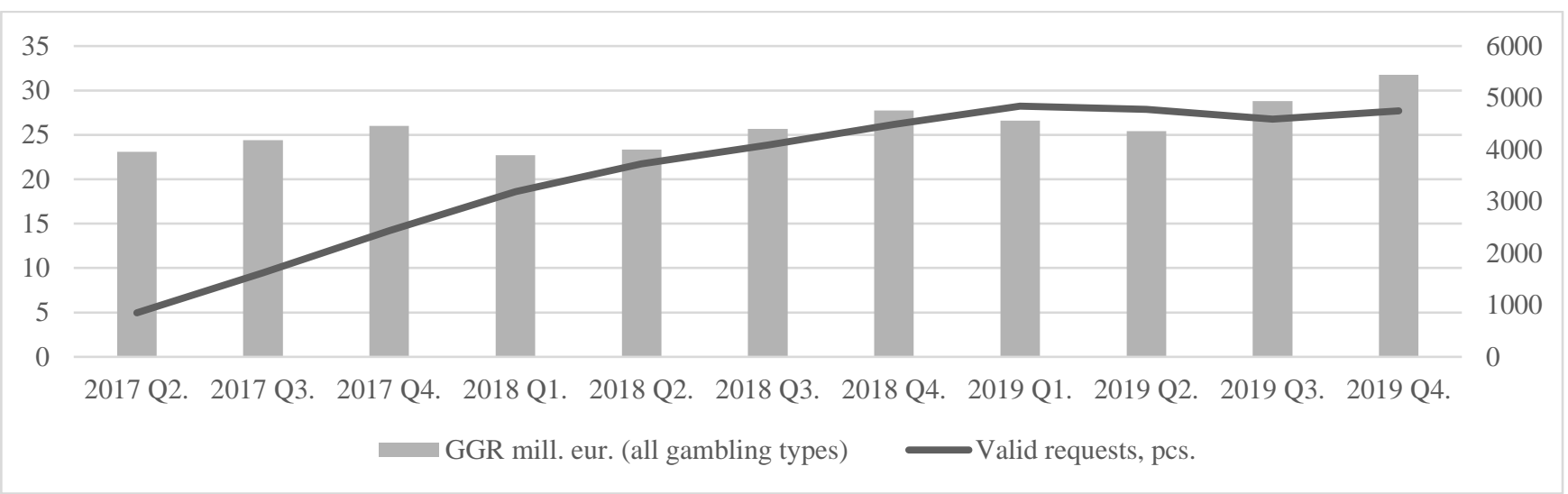

Figure 1. Change in GGR and in the Number of Valid Requests to Self-Exclude from Gambling Since May 1, 2017

Source: Authors ' estimation based on gambling operators 2017-2019 performance reports submitted in Gaming Control Authority under the Ministry of Finance of the Republic of Lithuania web page.

When analysing GGR changes of gambling operators we also need to take into consideration the current economic situation in the country. During the considered period (from Q2 2017 to Q4 2019), the country's gross domestic product (GDP) grew steadily, reflecting the country's overall economic growth. With the growth of GDP, the income of the population increased, the quality of life improved, and people could spend more on entertainment, including gambling. As people spend more money on gambling, gambling operators' GGR is growing, but unlike revenue growth the increase in the number of addicted gamblers is not immediately noticeable, so the negative impact on revenue may be delayed or not be so significant as to be seen in correlation analysis due to the countries growing economy.

In order to evaluate GGR of gambling sector and to forecast GGR change, current economic situation in the country was taken into account therefore GGR and GDP dependency was analysed. In this way we are seeking to determine if according to total economic growth, GGR of gambling operators was growing at the same pace that we could forecast according to GDP growth.

In order to determine the existence of a stochastic relationship between GGR and GDP, a paired correlation analysis (since 2008 to 2017) was performed and a correlation coefficient of 0.946286 was obtained (see Table 1 ).

Table 1

Correlation between GGR and GDP

\begin{tabular}{|c|c|c|}
\hline Year & GGR mill. EUR & GDP mill. EUR \\
\hline 2008 & 70,4 & 32696.3 \\
\hline 2009 & 49,6 & 26934.8 \\
\hline 2010 & 44,6 & $27,955.3$ \\
\hline 2011 & 52 & $31,233.7$ \\
\hline 2012 & 60,4 & $33,331.7$ \\
\hline 2013 & 68 & $34,985.0$ \\
\hline 2014 & 79,4 & $36,544.8$ \\
\hline 2015 & 85,6 & $37,321.8$ \\
\hline 2016 & 90,9 & $38,893.4$ \\
\hline $\begin{array}{c}\text { Correlation } \\
\text { coefficient, } \mathbf{r}\end{array}$ & 0,946286 \\
\hline
\end{tabular}

Source: Authors ' estimation based on statistical data submitted in Eurostat web page and gambling operators 2008-2016 performance reports submitted in Gaming Control Authority under the Ministry of Finance of the Republic of Lithuania web page
According to the calculated correlation coefficient value it can be concluded that there is a strong connection between GGR and GDP. The significance of the correlation coefficient value is verified by comparing sample statistics $\mathrm{t}$ with the critical value of sample statistics $t_{(0,05 ; 7)}^{\text {critical }}$. Since we obtained that $t>t_{(0,05 ; 7)}^{\text {critical }}$, we can conclude that the correlation coefficient $r=0.946286$ is significant and there is a stochastic relationship between GGR and GDP. Therefore we use regression analysis to calculate coefficients for linear regression equation $(\hat{y}=$ $-59,461575+0,00378815 x)$ by which with the projected GDP amount for next year we can find the expected average GGR and a graph of the curve which best represent the totality of statistical point (see Figure 2).

An analysis of the graph shows that after evaluation of GDP for 2017 (42269.4 mill. Eur), GDP for 2018 (45264.4 mill. Eur) and GDP for 2019 (48302.3 mill. Eur), GGR of gambling sector in 2017-2018 didn't grow as much as could be predicted according to GDP growth and economic situation of the country.

According to the country's growing economy and obtained linear regression equation the gambling sector GGR in 2017 had to reach 100.66 mill. Eur., in 2018 - 112 mill. Eur. and in 2019 - 123.52 mill. Eur. After analysing a data (from 2017 to 2019) we get that GGR of gambling operators in 2017 was lower by 3.30 mill. Eur, in 2018 was lower by 12.57 mill. Eur, and in 2019 lower by 10.90 mill. Eur. It can be concluded that while the income of the population was increasing and more income could be spent on gambling, the revenue from the gambling sector had a higher growth potential in terms of total economic growth in Lithuania and the opportunity to fill a request from May 1,2017 may have had an influence to a slowdown in GGR growth. 


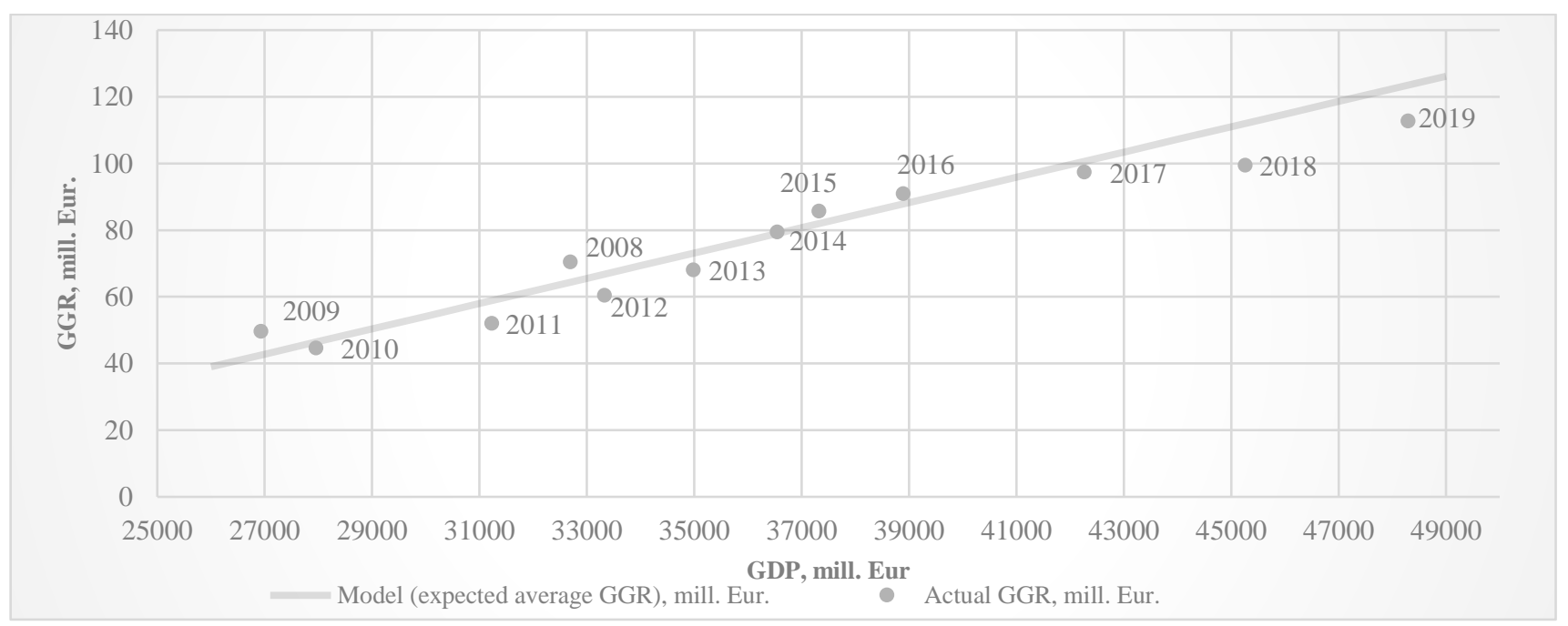

Figure 2. Model for Expected Average GGR

Source: Authors 'estimation

\section{Conclusions}

So far there is no consent among scientists what negative externalities should be considered as the economic social costs caused by gambling. As a consequence this allowed to make different conclusions about the impact of social costs caused by gambling negative externalities to the economy.

After scientific literature analysis it can be concluded that five types of costs create the economic social costs of gambling: costs of legal services and law enforcement agencies, costs of recruitment, treatment, outstanding loan recovery and other government expenditure (education, research, prevention, etc.). Noteworthy, that economic social costs of gambling should be analysed considering the harm to society caused only by gambling addiction and just negative technological externalities should be evaluated in researches. In order to evaluate real gambling impact on economy, further researches about social cost of gambling, should be executed.

Analysis showed that growing number of requests to self-exclude from gambling didn't had a clear effect on GGR of gambling operators, because paired correlation analysis of requests and GGR for separate types of gambling (from Q2 2017 to Q4 2019) did not produce a significant negative correlation, as a result, it cannot be concluded that there is a direct negative impact of requests to GGR for separate types of gambling. However, the increase in the number of addicted gamblers is not so immediately noticeable so the negative impact on GGR may be delayed or not be so significant as to be seen in correlation analysis due to the countries growing economy.

According to the calculated correlation coefficient value analysis revealed that there is a strong connection between GGR and GDP. By obtained linear regression equation with the projected GDP amount for next year we can find the expected average GGR (model for expected average GGR). Data analysis showed that GGR of gambling operators in 2017 was lower by 3.30 mill. Eur, in 2018 was lower by 12.57 mill. Eur, and in 2019 lower by 10.90 mill. Eur. It can be concluded that GGR from the gambling sector had a higher growth potential in terms of total economic growth in Lithuania and the opportunity to submit a request from May 1,2017 may have had an influence to a slowdown in GGR growth, but in order to evaluate long-term impact further researches should be executed.

\section{References}

Alarie, B., \& Ingelman, A. (2008). Bet on It: The Taxation of Online Gambling. In David W. Chodikoff \& James L. Horvath (eds.), The Taxation and Valuation of Technology (pp. 115-138). Irwin Law, 2008.

Barker, T., \& Britz, M. (2000). Jokers Wild: Legalized Gambling in the Twenty-first Century. Westport, Connecticut, London: Praeger.

Blaszczynski, A., et al. (2004). A Science-Based Framework for Responsible Gambling: The Reno Model. Journal of gambling studies, 20(3), 301-317. Available from internet: https://www.researchgate.net/publication/8359878_A_ Science-Based_Framework_for_Responsible_Gambling_The _Reno _Model. https://doi.org/10.1023/B:JOGS. 0000040281.49444.e2

Boardman, B., \& Perry, J. J. (2007). Access to gambling and declaring personal bankruptcy. The Journal of SocioEconomics, 36 (5), 789-801. https://doi.org/10.1016/j.socec.2007.01.012 
Iveta Simberova, Rima Zitkiene, Irena Macerinskiene, Greta Geneliene. The Evaluation of Gambling Sector's...

Chalaguine, A. (2018). Costs and benefits of Internet gambling for society (evidence from the United Kingdom). Journal of the Belarusian State University. Economics, 2018(2), 22-33. Available from internet: https://ssrn.com/abstract=3242987

Coryn, T., et al. (2008). Economic Aspects of Gambling Regulation: EU and US Perspectives. Martinus Nijhoff Publishers. https://doi.org/10.1163/ej.9789004165595.i-208

Eurostat. Anual national accounts, main GDP aggregates. Available from internet: https://ec.europa.eu/eurostat/web/ national- accounts/data/database, (accessed 1 December 2019).

Fiedler, I. (2013). Online gambling as a game changer for money laundering? In Otsch, W., Grozinger, G., Beyer, K., Brautigam, L. (Eds.), The political economy of offshore jurisdictions (pp. 79-95). Marburg, Germany: Metropolis. https://doi.org/10.2139/ssrn.2261266

Ginevicius, R. (2019). Problems of Harmony in the Development of Socio-Economic Systems. Inzinerine EkonomikaEngineering Economics, 30(2), 195-202. https://doi.org/10.5755/j01.ee.30.2.22869

Goodman, R. (1994). Legalized gambling as a strategy for economic development. Northampton, MA: United States Gambling Study.

Grebliauskas, A. (2009). Azartiniu losimu apmokestinimo ypatumai. Taikomoji ekonomika: sisteminiai tyrimai, 2009.3/1, $163-174$.

Grebliauskas, A. (2011). Viesoji losimu politika: losimu rinkos segmentavimo butinybe. Organizaciju vadyba: sisteminiai tyrimai, 2011.60, 63-77.

Grinols, E. L. (2004). Gambling in America: Costs and benefits. - New York: Cambridge University Press. https://doi.org/10.1017/CBO9780511510915

Holcombe, R. G., \& Sobel, R. S. (2001). Public policy toward pecuniary externalities. Public Finance Review, 29 (4), $304-$ 325. https://doi.org/10.1177/109114210102900402

Lietuvos Respublikos azartiniu losimu istatymas. Available from internet: https://www.e-tar.lt/portal/lt/legalAct/TAR.E5 509883EBB4/CxZdwzARMS, (accessed 1 December 2019).

Lietuvos statistikos departamentas. Pagrindiniai salies rodikliai. Available from internet: https://osp.stat.gov.lt/ pagrindiniai- salies-rodikliai. (accessed 15 February 2020).

Lojpur, A., \& Draskovic V. (2013). Institutional context of corporate governance and corporate social responsibility. Montenegrin Journal of Economics, 9 (1).

Losimu organizatoriu 2002-2017 metu veiklos rodikliai. Available from internet: http://lpt.lrv.lt/uploads/lpt/documents/ files/Losimo\%20organizatoriu\%202002\%20-\%202017\%20metu\%20veiklos\%20rodikliai.pdf ， (accessed 1 December 2019).

Losimu organizatoriu 2018 metu veiklos rodikliai. Available from internet: http://lpt.lrv.lt/uploads/lpt/documents/ files/Losimu\%20organizatoriu\%202018\%20metu\%20veiklos\%20rodikliai(1).pdf, (accessed 1 December 2019).

Losimu organizatoriu 2019 metu veiklos rodikliai. Available from internet: http://lpt.lrv.lt/uploads/lpt/documents/ files/Losimu\%20organizatoriu\%202019\%20metu\%20veiklos\%20rodikliai.pdf(accessed 1 December 2019).

Losimu prieziuros tarnybos prie Lietuvos Respublikos finansu ministerijos internetinis puslapis. Pagalba losejams. Naudinga informacija ir statistika. Available from internet: http://lpt.lrv.lt/lt/pagalba-losejams/naudinga-informacijair-statistika, (accessed 1 December 2019).

Melnikiene, R., et al. (2018). Tvaraus zemes ukio vystymasis: politikos formavimas ir apribojimu vertinimas. Viesoji politika ir administravimas, 17(2), 226-239.

Morkevicius, V. (2016). Pasaulines finansu krizes poveikis viesojo ir privaciojo sektoriaus darbuotoju subjektyvioms gyvenimo ir darbo salygoms. Viesoji politika ir administravimas, 15 (3), 425-444.

Philander, K. S. (2013). A normative analysis of gambling tax policy. UNLV Gaming Research \& Review Journal, 17(2), $17-26$.

Solferino, N. et al. (2018). A Dynamic Model of Gambling Addiction with Social Costs: Theory and Policy Solutions. Modern Economy, 9 (12), 2039-2051. https://doi.org/10.4236/me.2018.912127

Stanikunas, R. (2010). Valdzios kisimasis i rinka ir jo poveikis konkurencijai. Pinigu studijos, 2010/1.

The Oxford Handbook of the economics of gambling (2013). Edited by Williams, L. V. \& Siegel D. S. Oxford University Press.

Volodzkiene, L. (2018). The diversity of material living conditions (housing inequality): Lithuanian case. Intellectual Economics, 12(1), 59-72. 
Zickiene, S. (2007). Cooperation in Environmental Governance - a New Tool for Environment Protection Progress. Inzinerine Ekonomika-Engineering Economics, 53 (3), 42-50.

Walker, D. M. (2013). Casinonomics: the socioeconomic impacts on the casino industry. New York: Springer. https://doi.org/10.1007/978-1-4614-7123-3

Walker, D. M., \& Hodges, C. D. (2018). Gambling Taxes. Excerpt from Adam J. Hoffer \& Todd Nesbit (eds.), For Your Own Good: Taxes, Paternalism, and Fiscal Discrimination in the Twenty-First Century. Arlington, VA: Mercatus Center at George Mason University.

Walker, D. M., \& Barnett, A. H. (1999). The social costs of gambling: an economic perspective. Journal of gambling studies, 15(3), 181-212. https://doi.org/10.1023/A:1023089111024

Walker, D. M., et al. (2014). Setting Win Limits: An Alternative Approach to "Responsible Gambling"?. Journal of Gambling Studies, 31, 965-986. https://doi.org/10.1007/s10899-014-9453-6

Walker, D. M., \& Jackson, J. D. (2013). Casinos and economic growth: an update. The Journal of Gambling Business and Economics, 7 (2), 80-87. https://doi.org/10.5750/jgbe.v7i2.757

Walker, D. M., \& Sobel, R. S. (2016). Social and economic impacts of gambling. Current Addiction Reports, 3, $293-298$. https://doi.org/10.1007/s40429-016-0109-8

Walker, D. M. (2008). Clarification of the social costs of gambling. Journal of Public Budgeting, Accounting \& Financial Management, 20 (2), 141-152. https://doi.org/10.1108/JPBAFM-20-02-2008-B001

Walker, D. M. (2010). Casinos and crime in the USA. Handbook on the Economics of Crime. In: Bruce L. Benson \& Paul R. Zimmerman (ed.), Handbook on the Economics of Crime, Edward Elgar Publishing.

The article has been reviewed.

Received in April 2020; accepted in December 2020.

This article is an Open Access article distributed under the terms and conditions of the Creative Commons Attribution 4.0 (CC BY 4.0) License (http://creativecommons.org/licenses/by/4.0/). 